\title{
Gross Domestic Product, Number of Employees and Inflation Rate and Its Relationship to Private Final Consumption in Jordan
}

\author{
Adnan Abdelkarim Thiabat ${ }^{1} \&$ Taghreed Musleh Kattoua ${ }^{2}$ \\ ${ }^{1}$ Economy and Management in Agriculture, AL-Balqa Applied University, Jordan \\ ${ }^{2}$ Business Administration, AL-Balqa Applied University, Jordan \\ Correspondence: Dr. Adnan Abdelkarim Thiabat, Economy and Management in Agriculture, AL-Balqa Applied \\ University, Jordan.
}

Received: April 25, 2020

Accepted: July 23, 2020

Online Published: October 4, 2020

doi:10.5430/ijfr.v11n5p334

URL: https://doi.org/10.5430/ijfr.v11n5p334

\begin{abstract}
Jordan is affected by an increase in the ratio of public debt to a percentage of GDP. The increase rate has reached $85.8 \%$ (Jordan's central bank in numbers). And this is a serious indicator that affects the economic conditions and living standards. The study dealt with the final private consumption and the factors affecting it. The first factor is the gross domestic product (GDP), and it is a reverse view of influence, consumption is one of the components of GDP through spending, which is influential and influenced by it, the second factor was the demographic effect, and the study took the number of workers as part of the demographic factor and the third factor is the level of prices. The study took the rate of inflation. In cases of inflation and high prices, the state resorted to reducing public spending and increasing taxes to reduce actual demand (Hardan, Tahir 1997).

The study was from 2006 to 2016 as a sufficient period for measurement and the availability of accurate data. The study found that there is a relationship between the first and second variable and denied the relationship to the third variable, due to price fluctuations in the study period and one of the most important recommendations was to replace local labor with foreign labor.
\end{abstract}

Keywords: private consumption, inflation, unemployment, the number of workers

\section{Introduction}

The income that represents the value of the local or national product is considered one of the important economic indicators that measure the ability of the national economy to produce goods and services, so any economy in the world produces many different commodities such as wheat, meat, cars, and electrical appliances, and it also produces many services such as education, health, transportation and tourism services and, when we give a monetary value to these goods and services that an economy produces during a specific period of time, it is the collection of these values that are expressed in the local product.

The local product represents a flow because it reflects what was produced of goods and services during a certain period of time, and the increase in the size of the domestic "output" from one year to another means an increase in what the economy produces of goods and services, and this, in turn, means an increase in employment opportunities for members of society, which increases their income and increases which in turn increases their consumption investment, which increases production again and so on, and the opposite is true, and when an economy is unable to increase its goods and services it produces from year to year, this means an increase in the number of unemployed people, a decrease in incomes and a recession in society (Battal, 2020)

\subsection{Study Problem}

The essence of the economic problem is that the economic resources available to a person are limited and not sufficient to meet their needs and desires, and this is the essence of the economic problem (Bani Hani, Abdel Razzaq 2013).

The problem of the study is that the factors affecting consumption in Jordan have a strong influence on consumption or not? 
And that the gross domestic product affects consumption, knowing that consumption is the face of total spending, that is, the increase or decrease of the product has an effect on consumption and its amount?

\subsection{Study Objectives}

The purpose of this topic is about trying to achieve the following goals:

1. Clarify the concept of consumption and some of the theories explained to it.

2. Explain the consumer price index and methods of measuring inflation.

3. Explain the concept of the work force, workers, and unemployment rate.

4. Explain the effect of GDP on consumption.

\subsection{The Importance of the Study}

This study tries to shed light on private consumption and factors affecting it. The importance that consumption plays in the local production turnover, as consumption is the engine of production, and as the economic recession negatively affects economic activity, it was important to identify the factors affecting consumption in Jordan.

\subsection{Study Variables}

The study took the effect of the gross domestic product as a driver on consumption and from the demographic factor we took the number of workers as a driver as the strategic planning in human resources management represents the process of linking and integrating with the strategic goals and objectives to improve work production (Hammoud, Khudair 2007).

The rate of inflation is a factor in the price level, and from it we form three equations, namely:

\section{The first equation}

Independent variable: gross domestic product

Dependent variable: private consumption

The second equation

Independent variable: number of operators

Dependent variable: private consumption

\section{The third equation}

Independent variable: the rate of inflation

Dependent variable: private consumption

\subsection{Study Hypotheses}

The study relies on three assumptions based on economic logic that the relationship between the domestic product and the number of workers on the one hand and private consumption is positive. And the relationship between the rate of inflation and private consumption is negative where Tthe assumptions depend on the existence of the relationship and its effect or negation of the relationship and influence, and they are as follows:

\section{First:}

Null hypothesis H0: There is a positive direct relationship between GDP and private consumption at the significance level (0.05).

Alternative hypothesis H1: that there is no positive direct relationship between GDP and private consumption at the level of significance (0.05).

\section{Second:}

Null hypothesis $\mathrm{H} 0$ : There is a positive direct relationship between the number of workers and private consumption at the significance level (0.05).

Alternative hypothesis H1: there is no positive direct relationship between the number of workers and private consumption at the level of significance (0.05).

\section{Third:}

Null hypothesis H0: There is a negative relationship between the rate of inflation and private consumption at the significance level (0.05). 
Alternative hypothesis H1: there is no negative relationship between the rate of inflation and private consumption at the level of significance (0.05).

\section{Theoretical Framework and Previous Study}

\subsection{Theoretical Framework}

Private consumption

Consumption is defined as individuals spending their salaries on goods and services in order to satisfy their desires and maximize the benefit accrued from that.

Private consumption is divided into two types of goods (Al-Wazani, Khaled 2009).

First: non-durable goods, which are goods that satisfy it by just consuming it like food.

Second: durable goods, which are goods that satisfy it for long periods of time and are not used for one time, such as a car or home. In addition to services such as health and education

Also, the factors that affect consumption are many, including the income level, the price level, the interest rate, the wealth, the demographic effect, the simulated tastes, social factors, etc.

There are theories that explain consumption, we mention them:

1. Friedmen theory 1957 (Awad, Talib 2015), which is based on the fact that income consists of two parts: permanent income and temporary income

$\mathrm{Y}=\mathrm{Yp}+\mathrm{Yt}$

And by considering what is happening to the individual from the income that is known during the life period as a permanent income, either what happens to him in the length of this period from entering secondary commissions or bonuses is temporary Therefore, consumption is related to the type of income, so it is permanent and temporary consumption.

$\mathrm{C}=\mathrm{Cp}+\mathrm{Ct}$

2. Life Cycle Theory for F. Modigliani and Ando (Omaro Hassan 2018) The theory depends on time as the person at the beginning of his life and at the end of his life decreases his consumption because the income during this period is small while the average life is a high income due to productivity at this age, the theory also established that the individual at the age of productivity increases his savings with consumption as well, whereas, at the end of his life he spends these savings for consumption, thereby linking consumption to the individual's circumstances, age and social reality.

3. Keynesian theory of John Maynard Keynes (Dawod, Hussam 2010)

Which is based on that consumption is divided into two parts, independent or automatic consumption, which is consumption at zero income, and the second part, induced or continued consumption, which is the part related to income.

$\mathrm{C}=\mathrm{Co}+\mathrm{mpc}^{*} \mathrm{y}$

whereas

Co: Automatic consumption

MPC: Marginal propensity to consume

$\mathrm{Y}$ : income

Keynes explained that mpc is a boundary mile between zero and one

$0<\mathrm{mpc}<1$

The marginal slope of saving mps added to the mechanism of the marginal slope of consumption mpc equals one $\mathrm{mpc}+\mathrm{mps}=1$ 
Table 1. GDP and private consumption spending in Jordan from (2006 to 2016)

\begin{tabular}{llllll}
\hline $\begin{array}{l}\text { Consumption } \\
\text { ratio to GDP\% }\end{array}$ & $\begin{array}{l}\text { Private } \\
\text { consumption spending } \\
\text { Million dollars }\end{array}$ & $\begin{array}{l}\text { Private } \\
\text { consumption spending } \\
\text { Million dinars }\end{array}$ & $\begin{array}{l}\text { Gross domestic } \\
\text { product } \\
\text { Million dollars }\end{array}$ & $\begin{array}{l}\text { Gross domestic } \\
\text { product } \\
\text { Million dinars }\end{array}$ & Year \\
\hline 79.5 & 11947 & 8482 & 15036 & 10675 & 2006 \\
\hline 80.3 & 13726 & 9745 & 17086 & 12131 & 2007 \\
\hline 82.6 & 18321 & 13008 & 22192 & 15756 & 2008 \\
\hline 75.2 & 18001 & 12781 & 23944 & 17000 & 2009 \\
\hline 73.7 & 19544 & 13876 & 26520 & 18829 & 2010 \\
\hline 81.1 & 23430 & 16635 & 28907 & 20524 & 2011 \\
\hline 85.8 & 26538 & 18842 & 30935 & 21964 & 2012 \\
\hline 91.0 & 30577 & 21710 & 33617 & 23868 & 2013 \\
\hline 88.2 & 31793 & 22573 & 36051 & 25596 & 2014 \\
\hline 85.8 & 32524 & 23092 & 37923 & 26925 & 2015 \\
\hline
\end{tabular}

Source: General Statistics National Accounts.

Annual Estimates. Fourth revision (ISIC4) for Base year 2016

The dinar $=0.71 *$ the dollar

From Table 1, we note that consumption increased from 2006 to 2008 and reached 18321 million dollars, and in 2009 it decreased to 18001 million dollars. Then he continued to rise to 2016, when it reached 33623 million dollars, while the ratio of consumption to GDP was at the lowest estimate in 2010, when it reached 73.7\%, and in 2013 it reached the highest estimate and reached $91 \%$, while the gross domestic product continued to rise from 2006 and amounted to 15036 million dollars to 2016 and reached 39197 million dollars.

Table 2. Labor force statistics, number of employees, unemployment rate and foreign currency (2006-2016)

\begin{tabular}{|c|c|c|c|c|c|c|c|c|c|c|c|}
\hline \multirow[b]{2}{*}{ The indicator } & \multicolumn{11}{|l|}{ Year } \\
\hline & 2006 & 2007 & 2008 & 2009 & 2010 & 2011 & 2012 & 2013 & 2014 & 2015 & 2016 \\
\hline Labor force & 1227237 & 1312649 & 1342815 & 1400805 & 1412134 & 1436020 & 1443563 & 1444699 & 1460817 & 1607599 & 1660256 \\
\hline $\begin{array}{l}\text { The number of male } \\
\text { workers }\end{array}$ & 912065 & 961059 & 991990 & 1024529 & 1033015 & 1041263 & 1056003 & 1065318 & 1088865 & 1173730 & 1177245 \\
\hline $\begin{array}{l}\text { The number of } \\
\text { female workers }\end{array}$ & 143782 & 179387 & 180711 & 195991 & 202933 & 209708 & 212090 & 197318 & 197823 & 224300 & 229395 \\
\hline $\begin{array}{l}\text { Total number of } \\
\text { employees }\end{array}$ & 1055847 & 1140446 & 1172701 & 1220520 & 1235948 & 1250971 & 1268093 & 1262636 & 1286688 & 1398030 & 1406640 \\
\hline $\begin{array}{l}\text { Male unemployment } \\
\text { rate\% }\end{array}$ & 11.9 & 10.3 & 10.1 & 10.3 & 10.4 & 11 & 10.4 & 10.6 & 10.1 & 11 & 13.3 \\
\hline $\begin{array}{l}\text { Female } \\
\text { unemployment rate\% }\end{array}$ & 25 & 25.6 & 24.4 & 24.1 & 21.7 & 21.2 & 19.9 & 22.2 & 20.7 & 22.5 & 24.1 \\
\hline $\begin{array}{l}\text { Overall } \\
\text { unemployment rate\% }\end{array}$ & 14 & 13.1 & 12.7 & 12.9 & 12.5 & 12.9 & 12.2 & 12.6 & 11.9 & 13 & 15.3 \\
\hline
\end{tabular}

Source: Jordanian Ministry of Labor

Annual reports 2016 and 2011 
From Table 2 we note that the workforce in 2016 reached 1660,256 workers and it was increasing from 2006, and the number of workers increased from 2006 to 1055847 employees to 2016 as they numbered 1406640 workers and decreased in 2013 to 1262636 , the percentage of males was always higher than females, and the percentage of females was at the lowest level in 2006 and reached 143782 and the highest level in 2016 and It reached 229395, while the unemployment rate was at its lowest level in 2014 at 11.9 and the highest level in 2016 at 15.3 where the unemployment rate was always high for females, as it reached 25.6 in 2007, while male unemployment was 13.3, the highest in 2016.

Table 3. General consumer price index (2006-2016)

\begin{tabular}{llllllllllll}
\hline & Year & & & & & & & & & & \\
\hline Month & 2006 & 2007 & 2008 & 2009 & 2010 & 2011 & 2012 & 2013 & 2014 & 2015 & 2016 \\
\hline 1 & 78.55 & 83.54 & 87.81 & 94.6 & 100 & 103 & 106.18 & 112.54 & 116.28 & 116.46 & 115.24 \\
\hline 2 & 78.12 & 83.62 & 93.08 & 94.44 & 100 & 102.53 & 105.81 & 113.15 & 116.78 & 114.8 & 113.93 \\
\hline 3 & 78.09 & 83.87 & 94.66 & 94.18 & 100 & 102.85 & 106.61 & 113.53 & 117.27 & 115.84 & 113.91 \\
\hline 4 & 79.83 & 83.78 & 95.58 & 94.02 & 100 & 103.57 & 107.88 & 113.47 & 117.39 & 116.14 & 114.76 \\
\hline 5 & 80.77 & 83.45 & 95.51 & 94.12 & 100 & 103.64 & 107.7 & 112.5 & 116.72 & 116.47 & 114.64 \\
\hline 6 & 80.6 & 83.33 & 96.22 & 94.19 & 100 & 103.92 & 108.24 & 113.45 & 116.99 & 117.38 & 114.8 \\
\hline 7 & 80.57 & 83.13 & 98.07 & 94.5 & 100 & 104.08 & 109.16 & 114.09 & 117.65 & 116.92 & 116.43 \\
\hline 8 & 80.79 & 83.68 & 98.68 & 96.57 & 100 & 104.77 & 109.92 & 114.58 & 117.99 & 117.12 & 116.47 \\
\hline 9 & 81.54 & 84.74 & 100.59 & 97.1 & 100 & 104.99 & 110.14 & 115.17 & 118.2 & 116.81 & 115.94 \\
\hline 10 & 81.95 & 85.38 & 99.46 & 96.34 & 100 & 105.1 & 110.37 & 115.71 & 118.23 & 116.84 & 116.21 \\
\hline 11 & 82.17 & 86.06 & 98.4 & 96.93 & 100 & 105.41 & 111.93 & 115.28 & 117.74 & 115.97 & 116.55 \\
\hline 12 & 82.96 & 87.18 & 95.05 & 97.59 & 100 & 106.14 & 112.5 & 116 & 117.93 & 116.07 & 117.05 \\
\hline $\begin{array}{l}\text { Cumulativ } \\
\text { e index }\end{array}$ & 80.495 & 84.313 & 96.093 & 95.38 & 100 & 104.17 & 108.87 & 114.12 & 117.43 & 116.4 & 115.49 \\
\hline
\end{tabular}

Source: General Statistics

Consumer price indices (2006-2018), based on 2010

From Table 3, which expresses the consumer price index from 2006 to 2016 in each month of the year, considering that 2010 is a base year, we notice a marked decrease in the cumulative index, which is the average for all months of 2015 and 2016 over 2014.

Table 4. Cumulative index and inflation rates from 2006 to 2016

\begin{tabular}{lccccccccccc}
\hline \multicolumn{1}{l}{ The indicator } & \multicolumn{10}{c}{ Year } \\
\hline \multicolumn{1}{l}{$\begin{array}{l}\text { Cumulative } \\
\text { index }\end{array}$} & 2006 & 2007 & 2008 & 2009 & 2010 & 2011 & 2012 & 2013 & 2014 & 2015 & 2016 \\
\hline $\begin{array}{l}\text { Inflation } \\
\text { rate \% }\end{array}$ & 20.495 & 84.31333 & 96.0925 & 95.38167 & 100 & 104.1667 & 108.87 & 114.1225 & 117.4308 & 116.4017 & 115.4942 \\
\hline
\end{tabular}

Source Table 3

Consumer Price Index for the year $2005=78.225$

From Table 4, the inflation rate calculated with the cumulative consumer price index was obtained according to the following formula:

Inflation rate $=$ Cumulative index for the current year - Cumulative index for the previous year $/$ Cumulative index for the previous year* $100 \%$ 
We note the fluctuation in the inflation rate from one year to the next, as it reached the lowest level in 2009, a decrease of -0.74 and the highest level in 2008, amounting to 13.97.

This fluctuation and price instability can be explained by the economic factors affecting Jordan from neighboring countries and the external environment in intra-regional trade because of the wars surrounding Jordan.

In order to reach the standard analysis in explaining the factors affecting private consumption, we assume three equations and we test them according to the methodology mentioned above.

1. The relationship of GDP to private consumption

$\mathrm{PCO}=\mathrm{C} * \mathrm{GDP}$

Where

Dependent factor: PCO: private consumption

C: fixed function

Independent factor: GDP: Gross Domestic Product

2. The relationship between the number of workers and private consumption

$\mathrm{PCO}=\mathrm{C} * \mathrm{NE}$

Where

Dependent factor: PCO: private consumption

C: fixed function

Independent factor: NE: Number of employees

3. The relationship of inflation to private consumption

$\mathrm{PCO}=\mathrm{C} * \mathrm{IN}$

Where

Dependent factor: PCO: private consumption

C: fixed function

Independent factor: IN: inflation rate

\subsection{Previous Studies}

The researcher reviewed some of the previous studies such as:

Luca et al. (2020) conducted a study entitled "Going beyond Gross Domestic Product as an indicator to bring coherence to the Sustainable Development Goals". The study talked about promoting the sustainable goals in a holistic way and not achieving one of them, but rather working to promote all goals, for example, enhancing the individual's share of gross domestic income and neglecting the other goals, and that consumption and production are linked, not separable, and that increased growth should not affect environmental stability, as the study addressed the gross domestic product of the European Union and it is not related to employment levels and that focusing on one goal of sustainable development may hinder the achievement of other goals. The study found in one of its results that growth in gross domestic product as a single measure may give false signals to policymakers.

The study of Klinger \& Weber (2020) entitled "GDP-employment decoupling in Germany". This study talked about the changing relationship between GDP growth and employment growth that reached 1.2\% between 2006 and 2018 and about the process of separation with the effect that is due to the phenomenon of labor hoarding, which helped the short-term support policies in the event of recession, which helped in performing the labor market well with the conditions of recession in the gross domestic product, as it is known to increase the unemployment rate in the event of economic recession.

Maciej et al, (2019) study entitled "Relations of GDP growth and development of SMEs in Poland". It aims to explain the relationship between the gross domestic product and small and medium-sized companies and the role of these companies in solving the problem of unemployment in Poland. One of the hypotheses of the study was that there was a direct relationship between the components of the gross domestic product, including consumption and the development of small and medium enterprises. The study took the period between the years 1996 and 2016 and the contribution of these companies in raising the added value. The study also concluded that qualified young people are able to enter the market with entrepreneurial projects if the means of support are available from workshops and 
training courses. This result is a practical example for other countries that may suffer from employment problems in conditions of economic stagnation to adopt German policies in separating the impact of stagnation on employment levels.

Svenfelt et al (2019) conducted a study entitled "Scenarios for sustainable futures beyond GDP growth 2050". The study examines that economic growth is not a single goal for sustainable development, but there are other important goals such as climate, land, and resource security, goals that are no less important than growth, and that the future of cooperative economics and achieving self-sufficiency, and that linking economic growth with prosperity is not always correct, so it can be a cause of environmental degradation, as the study said that technological development is not a weapon that threatens work and will increase the rates of heroism, but it may be a reason to create new opportunities. The narrators of this study focused on reducing consumption, depleting resources and urging the production.

Saleh Bassam's Study (2018) entitled Estimating the Total Consumption Function in the Palestinian Economy for the Period (1994-2016) The aim of the study is to estimate the function of total consumption in the Palestinian economy in the previous time period the study consisted of several chapters from general concepts about consumption and the Palestinian economic reality and then the consumption function in Palestine.

Al-Amr Hassan and others study (2018) titled Determinants of Family Savings in Jordan. The study examined the factors affecting savings, including private consumption, the price index and other factors during the period (1980-2014). The effect varied between factors and family saving, and there was a positive relationship between consumption, savings and savings, and he denied other relationships, while other inverse relationships were found. And one of the most important results was a negative relationship between the price index and family saving and a positive relationship between private consumption and family saving, which is consistent with what came in the life cycle theory.

Ibrahim Khalil study (2015) entitled the impact of excessive consumption on the environment and the stability of price levels in the Iraqi economy during the years (2005-2013) The study dealt with the concept of providing financial resources to society, especially oil states, especially in the classes that are not aware of the importance of consumption and the harmful consequences of its excess. The problem of the study was the negative effects of consumerism on the environment and price levels. Among the most important recommendations were cultural awareness in the area of spending and working to make decisions to counter price rises.

The study of Anghelache (2011) entitled "Analysis of the Correlation between GDP and the Final Consumption”, in which he presented the relationship between private final consumption and gross domestic product in Romania between 1990 and 2009 and he reached a direct relationship between consumption and GDP, as production increased with increasing consumption from 1990 to 2008, and the two decreased by 4-5\% after that. He reached the linear equation so that increasing the final private consumption of one monetary unit increases the gross domestic product by 1.21 monetary units.

\section{Methodology}

The researchers use the Engle-granger methodology which is in two stages

The first is to estimate the long-term equilibrium relationship model with a common integral regression

Second Estimation of the short-term relationship model (error correction model)

After testing residual stillness, self-correlation, Variation of variance, and normal distribution of residues.

\subsection{Study Tools and Scales}

For the purposes of proving or denying research hypotheses, a standard statistical analysis method will be adopted for all variables during the study period from 2006 to 2016 using standard methods for analyzing time series. It is the set of measurements and observations of data according to multiple time periods, and an appropriate number of chains is preferred (Al-Qadi, Dalal, 2005).

And after that, Unit Root Test, Dickey - Fuller (ADF), Common Integration, Long-Term Causal, and Error Correction Model as per Engle - Granger Methodology.

\subsection{Data Collection Method}

The public statistics reports, the Central Bank, and the Jordanian Ministry of Labor were approved for the period (2006-2016). Through annual reports and accredited websites, data is documented in each table from the same source. 


\section{Results of the Study}

\subsection{Testing the First Hypothesis}

$\mathrm{H} 0$ null hypothesis: There is a positive direct relationship between GDP and private consumption at the significance level (0.05).

Alternative hypothesis H1: that there is no positive relationship between GDP and private consumption at the level of significance (0.05)

We test it for the following equation: $\mathrm{PCO}=\mathrm{C}$ GDP

The first is $\mathrm{PCO}=\mathrm{C}$ GDP

The second $\mathrm{PCO}=\mathrm{C} \mathrm{NE}$

The third $\mathrm{PCO}=\mathrm{C}$ IN

The first equation

We apply the ADF test, to test time Series Stability using the data from Table 1.

Table 5. Unit root test results (ADF)

\begin{tabular}{|c|c|c|c|}
\hline \multicolumn{4}{|c|}{ Null Hypothesis: the variable has a unit root } \\
\hline & \multicolumn{3}{|c|}{ At Level } \\
\hline & & PCO & GDP \\
\hline \multirow[t]{3}{*}{ With Constant } & t-Statistic & -0.8704 & -3.6427 \\
\hline & Prob. & 0.7524 & 0.0292 \\
\hline & & n0 & $* *$ \\
\hline \multirow[t]{3}{*}{ With Constant \& Trend } & t-Statistic & -1.7299 & -1.5658 \\
\hline & Prob. & 0.6616 & 0.7327 \\
\hline & & n0 & n0 \\
\hline \multirow[t]{5}{*}{ Without Constant \& Trend } & t-Statistic & 3.1548 & 4.7358 \\
\hline & Prob. & 0.9974 & 0.9998 \\
\hline & & n0 & n0 \\
\hline & At First I & rence & \\
\hline & & $\mathrm{d}(\mathrm{PCO})$ & $\mathrm{d}(\mathrm{GDP})$ \\
\hline \multirow[t]{3}{*}{ With Constant } & t-Statistic & -2.8271 & -3.3019 \\
\hline & Prob. & 0.0923 & 0.0471 \\
\hline & & $*$ & $* *$ \\
\hline \multirow[t]{3}{*}{ With Constant \& Trend } & t-Statistic & -2.8263 & -5.7633 \\
\hline & Prob. & 0.2291 & 0.0077 \\
\hline & & n0 & $* * *$ \\
\hline \multirow[t]{3}{*}{ Without Constant \& Trend } & $\mathrm{t}$-Statistic & -1.3980 & -2.4038 \\
\hline & Prob. & 0.1412 & 0.0238 \\
\hline & & n0 & $* *$ \\
\hline
\end{tabular}

\section{Notes:}

a: $(*)$ Significant at the 10\%; (**) Significant at the 5\%; $(* * *)$ Significant at the $1 \%$ and (no) Not Significant

b: Lag Length based on SIC

c: Probability based on MacKinnon (1996) one-sided p-values.

d: EViews 10 program 
From Table 5, we note that the strings are stable in the first difference.

We find the estimated regression equation by Least Squares.

Table 6. The estimated regression equation by the least squares

\begin{tabular}{lllll}
\hline $\begin{array}{l}\text { Dependent Variable: PCO } \\
\text { Method: Least Squares }\end{array}$ & & & \\
$\begin{array}{l}\text { Date: } 12 / 09 / 19 \quad \text { Time: } \\
\text { Sample: 2006 2016 }\end{array}$ & & & & \\
$\begin{array}{l}\text { Included observations: } 11 \\
\text { Variable }\end{array}$ & Coefficient & Std. Error $\quad$ t-Statistic & Prob. \\
C & -3160.177 & 1456.227 & -2.170112 & 0.0481 \\
GDP & 0.946624 & 0.049594 & 19.08741 & 0.0000 \\
\hline R-squared & 0.975893 & Mean dependent var & 23638.46 \\
Adjusted R-squared & 0.973214 & S.D. dependent var & 7832.679 \\
S.E. of regression & 1281.930 & Akaike info criterion & 17.31309 \\
Sum squared reside & 14790105 & Schwarz criterion & 17.38543 \\
Log likelihood & -93.22198 & Hannan-Quinn criter. & 17.26748 \\
F-statistic & 364.3292 & Durbin-Watson stat & 0.905247 \\
Prob(F-statistic) & 0.000000 & & & \\
\hline
\end{tabular}

* EViews 10 program

$$
\mathrm{PCO}=-3160.17693876+0.946623799949 * \mathrm{GDP}
$$

Notes on the previous Table 6:

Null hypothesis H0: The variable has significant significance if Prob> 0.05

Alternative hypothesis $\mathrm{H} 1$ : the variable has no significant significance if Prob>0.05

Prob (F-statistic) (0.000) is less than the level of significance (0.05), that is, there is a significant significance for F-statistic, and we take the null theory and say that $97.5 \%$ of the change in output is due to the independent factor GDP.

The prob for the independent variable (0.000) (GDP) is less than the significance level (0.05), meaning that there is a significant significance for (GDP) and we take the Nihilism theory.

The prob for the independent variable $(0.0481)$ (c) is less than the significance level $(0.05)$, meaning that there is significant significance for (c) and we take the null theory.

The estimated long-run regression equation is

$\mathrm{PCO}=-3160.17+0.946 *$ GDP

We are doing the ADF test

To test the residual stability, find the roots of the unit, and denote the remaining with the symbol (E1) according to the following table.

Table 7. Unit root test results (ADF)

\begin{tabular}{lll}
\hline \multicolumn{1}{l}{ Null Hypothesis: the variable has a unit root } \\
\cline { 2 - 3 } At Level & \\
\multirow{4}{*}{ With Constant } & E1 \\
& t-Statistic & -2.9766 \\
& Prob. & $\mathbf{0 . 0 7 4 7}$ \\
With Constant \& Trend & t-Statistic & -3.0863 \\
& Prob. & $\mathbf{0 . 1 6 8 4}$ \\
\hline
\end{tabular}




\begin{tabular}{|c|c|c|}
\hline & & n0 \\
\hline \multirow[t]{5}{*}{ Without Constant \& Trend } & $\mathrm{t}$-Statistic & -3.1947 \\
\hline & Prob. & 0.0053 \\
\hline & & $* * *$ \\
\hline & At First I & rence \\
\hline & & $\mathrm{d}(\mathrm{E} 1)$ \\
\hline \multirow[t]{3}{*}{ With Constant } & t-Statistic & -1.9331 \\
\hline & Prob. & 0.3052 \\
\hline & & n0 \\
\hline \multirow[t]{3}{*}{ With Constant \& Trend } & t-Statistic & -2.0424 \\
\hline & Prob. & 0.4959 \\
\hline & & n0 \\
\hline \multirow[t]{3}{*}{ Without Constant \& Trend } & t-Statistic & -2.0532 \\
\hline & Prob. & 0.0443 \\
\hline & & $* *$ \\
\hline
\end{tabular}

Notes:

a: $(*)$ Significant at the $10 \% ;(* *)$ Significant at the 5\%; $(* * *)$ Significant at the $1 \%$ and (no) Not Significant

b: Lag Length based on SIC

c: Probability based on MacKinnon (1996) one-sided p-values.

d: EViews 10 program

As it is clear from Table 7, it is noted that it is stable in the level

Table 8. Self-link test using Breusch-Godfrey test

\begin{tabular}{|c|c|c|c|c|}
\hline \multicolumn{5}{|c|}{ Breusch-Godfrey Serial Correlation LM Test: } \\
\hline F-statistic & 3.878742 & \multicolumn{2}{|c|}{ Prob. F(3,6) } & 0.0743 \\
\hline Obs*R-squared & 7.257703 & \multirow{2}{*}{\multicolumn{2}{|c|}{ Prob. Chi-Square(3) }} & 0.0641 \\
\hline \multicolumn{3}{|l|}{ Test Equation: } & & \\
\hline \multicolumn{5}{|c|}{ Dependent Variable: RESID } \\
\hline \multicolumn{5}{|c|}{ Method: Least Squares } \\
\hline Date: $12 / 09 / 19 \quad \mathrm{~T}$ & \multicolumn{4}{|c|}{ Time: 19:53 } \\
\hline \multicolumn{5}{|c|}{ Sample: 20062016} \\
\hline \multicolumn{5}{|c|}{ Included observations: 11} \\
\hline \multicolumn{5}{|c|}{ Presample missing value lagged residuals set to zero. } \\
\hline Variable & Coefficient & Std. Error & t-Statistic & Prob. \\
\hline $\mathrm{C}$ & 24.99232 & 1050.572 & 0.023789 & 0.9818 \\
\hline GDP & -0.001238 & 0.035936 & -0.034462 & 0.9736 \\
\hline $\operatorname{RESID}(-1)$ & 0.636291 & 0.393631 & 1.616467 & 0.1571 \\
\hline $\operatorname{RESID}(-2)$ & -0.371625 & 0.462750 & -0.803081 & 0.4526 \\
\hline $\operatorname{RESID}(-3)$ & -0.362086 & 0.414205 & -0.874172 & 0.4156 \\
\hline R-squared & 0.659791 & \multicolumn{2}{|c|}{ Mean dependent var } & $-3.41 \mathrm{E}-13$ \\
\hline Adjusted R-squared & 0.432985 & \multicolumn{2}{|c|}{ S.D. dependent var } & 1216.146 \\
\hline S.E. of regression & 915.7624 & \multicolumn{2}{|c|}{ Akaike info criterion } & 16.78035 \\
\hline Sum squared resid & 5031724. & \multicolumn{2}{|c|}{ Schwarz criterion } & 16.96121 \\
\hline Log likelihood & -87.29190 & \multicolumn{2}{|c|}{ Hannan-Quinn criter. } & 16.66634 \\
\hline F-statistic & 2.909056 & \multicolumn{2}{|c|}{ Durbin-Watson stat } & 1.735075 \\
\hline Prob(F-statistic) & 0.117317 & & & \\
\hline
\end{tabular}

* EViews 10 program

Null hypothesis H0: The presence of a Prob correlation> 0.05

Alternative hypothesis H1: No Prob correlation> 0.05 
We note from Table 8 that the prob-f value is equal to (0.0743) and it is greater than the level of significance (0.05). Therefore, we accept the null hypothesis, which is the existence of a second-degree correlation.

We are now testing the residual distribution by

Jarque-Bera Test

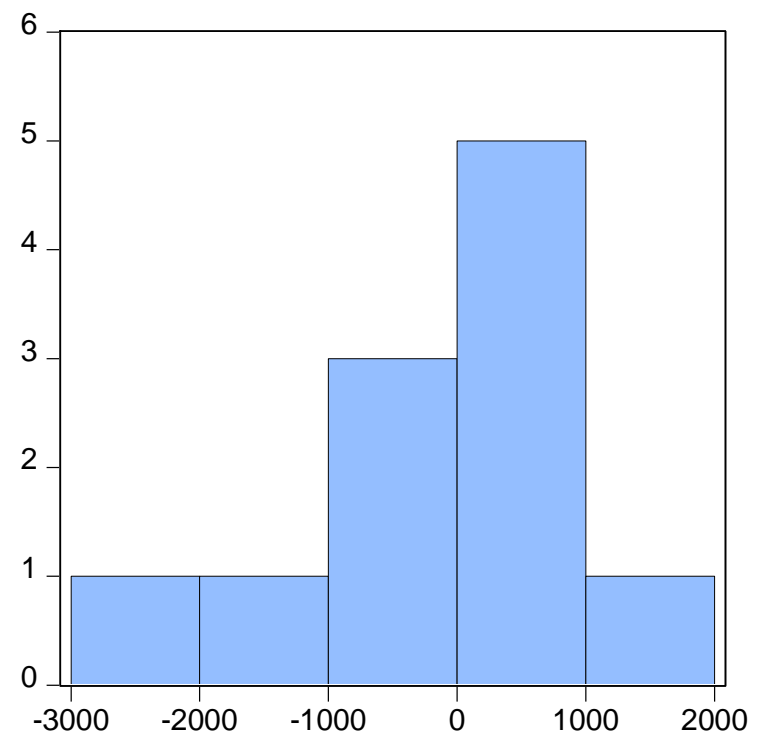

\section{Series: Residuals \\ Sample 20062016 \\ Observations 11}

Mean

$-3.41 e-13$

Median

414.1979

Maximum

1915.083

Minimum

$-2400.358$

Std. Dev. $\quad 1216.146$

Skewness $\quad-0.521690$

Kurtosis $\quad 2.691531$

Jarque-Bera $\quad 0.542573$

Probability $\quad 0.762398$

* EViews 10 program

Figure 1

Null hypothesis H0: The existence of normal distribution Prob> 0.05

Alternative hypothesis H1: There is no normal distribution Prob> 0.05

We note from figure 1 that the value of probability is equal to (0.762398) which is greater than the level of significance (0.05), so we accept the null hypothesis, which is the presence of a normal distribution of the remainder, and we notice that from the graphical representation

Table 9. Heteroskedasticity Test: ARCH

\begin{tabular}{|c|c|c|c|c|}
\hline F-statistic & 0.000224 & \multicolumn{2}{|c|}{ Prob. F $(1,8)$} & 0.9884 \\
\hline Obs*R-squared & 0.000280 & \multicolumn{2}{|c|}{ Prob. Chi-Square (1) } & 0.9867 \\
\hline \multicolumn{5}{|c|}{ Test Equation: } \\
\hline \multicolumn{5}{|c|}{ Dependent Variable: RESID^2 } \\
\hline \multicolumn{5}{|c|}{ Method: Least Squares } \\
\hline Date: $12 / 09 / 19$ & $9: 57$ & & & \\
\hline \multicolumn{5}{|c|}{ Sample (adjusted): 20072016} \\
\hline \multicolumn{5}{|c|}{ Included observations: 10 after adjustments } \\
\hline Variable & Coefficient & Std. Error & t-Statistic & Prob. \\
\hline $\mathrm{C}$ & 1394732. & 834611.5 & 1.671115 & 0.1332 \\
\hline $\operatorname{RESID}^{\wedge} 2(-1)$ & 0.005398 & 0.360789 & 0.014962 & 0.9884 \\
\hline $\begin{array}{l}\text { R-squared } \\
* \text { EViews } 10 \text { prc }\end{array}$ & 0.000028 & Mean de & lent var & 1402660. \\
\hline
\end{tabular}

Note from Table 9 that

Null hypothesis H0: There is a homogeneity in the error variance Prob> 0.05 
Alternative hypothesis H1: There is no homogeneity in the error variance Prob> 0.05

We take the nihilistic hypothesis. There is a homogeneity in the error variance F-statistic prob $(0.9884)>(0.05)$

We take the nihilistic hypothesis. There is a homogeneity in the error variance Obs*R-squaredprob $(0.9867)>(0.05)$

\section{Error Correction Form}

We add the error correction factor as an independent variable to the model to find the estimated regression equation in the short term.

Table 10. Least Squares

\begin{tabular}{|c|c|c|c|c|}
\hline \multicolumn{5}{|c|}{ Dependent Variable: DPCO } \\
\hline \multicolumn{5}{|c|}{ Method: Least Squares } \\
\hline \multicolumn{5}{|c|}{ Date: $12 / 09 / 19$ Time: $20: 04$} \\
\hline \multicolumn{5}{|c|}{ Sample (adjusted): 20072016} \\
\hline \multicolumn{5}{|c|}{ Included observations: 10 after adjustments } \\
\hline Variable & Coefficient & Std. Error & t-Statistic & Prob. \\
\hline DGDP & 0.935990 & 0.136005 & 6.882006 & 0.0001 \\
\hline E1(-1) & -0.476744 & 0.292718 & -1.628681 & 0.0420 \\
\hline R-squared & 0.583802 & \multicolumn{2}{|c|}{ Mean dependent var } & 2167.575 \\
\hline Adjusted R-squared & 0.531777 & \multicolumn{2}{|c|}{ S.D. dependent var } & 1635.668 \\
\hline S.E. of regression & 1119.236 & \multicolumn{2}{|c|}{ Akaike info criterion } & 17.05554 \\
\hline Sum squared resid & 10021506 & \multicolumn{2}{|c|}{ Schwarz criterion } & 17.11605 \\
\hline Log likelihood & -83.27768 & \multicolumn{2}{|c|}{ Hannan-Quinn criter. } & 16.98915 \\
\hline Durbin-Watson stat & 1.279135 & & & \\
\hline
\end{tabular}

* EViews 10 program

$$
\text { DPCO }=0.935990496323 * \text { DGDP }-0.476744198714 * \text { E1(-1) }
$$

Notes on the previous Table 10

Null hypothesis H0: The variable has significant significance if Prob>0.05

Alternative hypothesis $\mathrm{H} 1$ : the variable has no significant significance if Prob> 0.05

The prob for the independent variable (0.0001) (GDP) is less than the significance level (0.05), meaning that there is a significant significance for (GDP) and we take in the null hypothesis

The prob for the independent variable (0.0420) (E1) is less than the significant level (0.05), meaning that there is a significant significance for me (E1) in addition to the negative sign of the amount

If the estimated regression equation after correction is for the short term

$$
\mathrm{DPCO}=0.935^{*} \text { DGDP }-0.476 * \mathrm{E} 1(-1)
$$

\subsection{Testing the Second Hypothesis}

Null hypothesis H0: There is a positive direct relationship between the number of workers and private consumption at the significance level (0.05).

Alternative hypothesis H1: there is no positive direct relationship between the number of workers and private consumption at the level of significance (0.05).

And we put the following equation

$\mathrm{PCO}=\mathrm{C}$ NE second

And using the number 1 and 2

\section{The second equation}

We are doing the ADF test

Time Series Stability Test 
Table 11. Unit root test results (ADF)

\begin{tabular}{|c|c|c|c|}
\hline \multicolumn{4}{|c|}{ Null Hypothesis: the variable has a unit root } \\
\hline & & $\mathrm{PCO}$ & $\mathrm{NE}$ \\
\hline \multirow[t]{3}{*}{ With Constant } & t-Statistic & -0.8704 & -1.1554 \\
\hline & Prob. & 0.7524 & 0.6474 \\
\hline & & n0 & n0 \\
\hline \multirow[t]{3}{*}{ With Constant \& Trend } & t-Statistic & -1.7299 & -2.4996 \\
\hline & Prob. & 0.6616 & 0.3223 \\
\hline & & n0 & n0 \\
\hline \multirow[t]{5}{*}{ Without Constant \& Trend } & t-Statistic & 3.1548 & 2.8655 \\
\hline & Prob. & 0.9974 & 0.9957 \\
\hline & & n0 & n0 \\
\hline & At First D & rence & \\
\hline & & $\mathrm{d}(\mathrm{PCO})$ & $\mathrm{d}(\mathrm{NE})$ \\
\hline \multirow[t]{2}{*}{ With Constant } & t-Statistic & -2.8271 & -3.2462 \\
\hline & Prob. & $\begin{array}{l}0.0923 \\
*\end{array}$ & $\begin{array}{l}0.0510 \\
*\end{array}$ \\
\hline \multirow[t]{3}{*}{ With Constant \& Trend } & t-Statistic & -2.8263 & -3.0186 \\
\hline & Prob. & 0.2291 & 0.1823 \\
\hline & & n0 & n0 \\
\hline \multirow[t]{3}{*}{ Without Constant \& Trend } & t-Statistic & -1.3980 & -2.3638 \\
\hline & Prob. & 0.1412 & 0.0247 \\
\hline & & n0 & ** \\
\hline \multicolumn{4}{|c|}{ Notes: } \\
\hline \multicolumn{4}{|c|}{$\begin{array}{l}\text { a: }(*) \text { Significant at the } 10 \% ;(* *) \text { Significant at the } 5 \% ;(* * *) \text { Significant at the } 1 \% \text { and (no) Not Significant } \\
\text { b: Lag Length based on SIC } \\
\text { c: Probability based on MacKinnon (1996) one-sided p-values. } \\
\text { d: EViews } 10 \text { program }\end{array}$} \\
\hline
\end{tabular}

We note from Table 11 that the strings are stable in the first difference

Table 12. The estimated regression equation by the Least Squares

\begin{tabular}{lllll}
\hline $\begin{array}{l}\text { Dependent Variable: PCO } \\
\text { Method: Least Squares }\end{array}$ & & & \\
Date: $12 / 09 / 19 \quad$ Time: $21: 06$ & & & \\
Sample: 2006 2016 & & & & \\
Included observations: 11 & & & & \\
\hline Variable & Coefficient & Std. Error & t-Statistic & Prob. \\
\hline C & -63229.34 & 13096.63 & -4.827910 & 0.0009 \\
NE & 0.069755 & 0.010485 & 6.653177 & 0.0001 \\
\hline R-squared & 0.831033 & Mean dependent var & 23638.46 \\
Adjusted R-squared & 0.812259 & S.D. dependent var & 7832.679 \\
S.E. of regression & 3393.832 & Akaike info criterion & 19.26027 \\
Sum squared resid & $1.04 E+08$ & Schwarz criterion & 19.33262 \\
Log likelihood & -103.9315 & Hannan-Quinn criter. & 19.21467 \\
F-statistic & 44.26476 & Durbin-Watson stat & 1.131489 \\
Prob(F-statistic) & 0.000093 & & \\
\hline
\end{tabular}

* EViews 10 program

$$
\mathrm{PCO}=-63229.3358728+0.0697554010675 * \mathrm{NE}
$$


Notes on the previous Table 12

Null hypothesis H0: The variable has significant significance if Prob> 0.05

Alternative hypothesis H1: the variable has no significant significance if Prob>0.05

Prob (F-statistic) (0.000093) is less than the significance level (0.05), that is, there is a significant significance for F-statistic. We take the null theory and say that $83.1 \%$ of the change in output is due to the independent factor NE

The prob for the independent variable (0.0001) (NE) is less than the significance level $(0.05)$, meaning that there is significant significance for (NE) and we take the null theory.

The prob for the independent variable (0.0009) (c) is less than the significance level $(0.05)$, meaning that there is significant significance for (c) and we take the null theory

If the estimated long-run regression equation is

$$
\mathrm{PCO}=-63229.33+0.0697 * \mathrm{NE}
$$

We apply the ADF test

To test the residual stability and find the roots of the unit, we denote the remainder by symbol (E2) according to the following table

Table 13. Unit root test results (ADF)

\begin{tabular}{|c|c|c|}
\hline \multicolumn{3}{|c|}{ Null Hypothesis: the variable has a unit root } \\
\hline 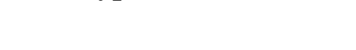 & $\underline{\text { At Level }}$ & \\
\hline & & E2 \\
\hline \multirow[t]{2}{*}{ With Constant } & t-Statistic & -1.8066 \\
\hline & Prob. & $\begin{array}{l}\mathbf{0 . 3 5 6 7} \\
\text { n0 }\end{array}$ \\
\hline \multirow[t]{2}{*}{ With Constant \& Trend } & t-Statistic & -1.9559 \\
\hline & Prob. & $\begin{array}{l}\mathbf{0 . 5 5 4 8} \\
\text { n0 }\end{array}$ \\
\hline \multirow[t]{4}{*}{ Without Constant \& Trend } & t-Statistic & -1.9213 \\
\hline & Prob. & $\begin{array}{l}0.0560 \\
*\end{array}$ \\
\hline & $\underline{\text { At First D }}$ & rence \\
\hline & & $\mathrm{d}(\mathrm{E} 2)$ \\
\hline \multirow[t]{2}{*}{ With Constant } & t-Statistic & -3.0124 \\
\hline & Prob. & $\begin{array}{l}0.0710 \\
*\end{array}$ \\
\hline \multirow[t]{2}{*}{ With Constant \& Trend } & t-Statistic & -2.8833 \\
\hline & Prob. & $\begin{array}{l}0.2162 \\
\text { n0 }\end{array}$ \\
\hline \multirow[t]{2}{*}{ Without Constant \& Trend } & t-Statistic & -3.2457 \\
\hline & Prob. & $\begin{array}{l}\mathbf{0 . 0 0 4 8} \\
* * *\end{array}$ \\
\hline
\end{tabular}

\section{Notes:}

a: (*) Significant at the 10\%; (**) Significant at the 5\%; (***) Significant at the $1 \%$ and (no) Not Significant

b: Lag Length based on SIC

c: Probability based on MacKinnon (1996) one-sided p-values.

d: EViews 10 program

From Table 13 we note that it is stable in the level

Self-link testing and we do it with Breusch-Godfrey test 
Table 14. Breusch-Godfrey Serial Correlation LM Test

\begin{tabular}{llll}
\hline F-statistic & 1.069739 & Prob. F(3,6) & 0.4295 \\
Obs*R-squared & 3.833267 & Prob. Chi-Square(3) & 0.2800 \\
\hline
\end{tabular}

Test Equation:

Dependent Variable: RESID

Method: Least Squares

Date: 12/09/19 Time: 21:10

Sample: 20062016

Included observations: 11

Presample missing value lagged residuals set to zero.

\begin{tabular}{lllll}
\hline Variable & Coefficient & Std. Error & t-Statistic & Prob. \\
\hline C & -1350.395 & 15030.15 & -0.089846 & 0.9313 \\
NE & 0.000946 & 0.012074 & 0.078360 & 0.9401 \\
RESID(-1) & 0.405757 & 0.382935 & 1.059598 & 0.3301 \\
RESID(-2) & 0.050769 & 0.518457 & 0.097923 & 0.9252 \\
RESID(-3) & -0.548318 & 0.529890 & -1.034777 & 0.3407 \\
\hline R-squared & 0.348479 & Mean dependent var & $1.24 \mathrm{E}-12$ \\
Adjusted R-squared & -0.085869 & S.D. dependent var & 3219.672 \\
S.E. of regression & 3355.060 & Akaike info criterion & 19.37728 \\
Sum squared resid & 67538556 & Schwarz criterion & 19.55814 \\
Log likelihood & -101.5751 & Hannan-Quinn criter. & 19.26327 \\
F-statistic & 0.802304 & Durbin-Watson stat & 2.312137 \\
Prob(F-statistic) & 0.565681 & & \\
\hline
\end{tabular}

* EViews 10 program

Null hypothesis H0: Prob correlation> 0.05

Alternative hypothesis H1: No Prob correlation> 0.05

We notice from Table 14 that the prob-f value is equal to (0.4295) and it is greater than the level of significance (0.05). Therefore, we accept the null hypothesis, which is the existence of a third-degree correlation.

Then, we test residual distribution using the Jarque-Bera test

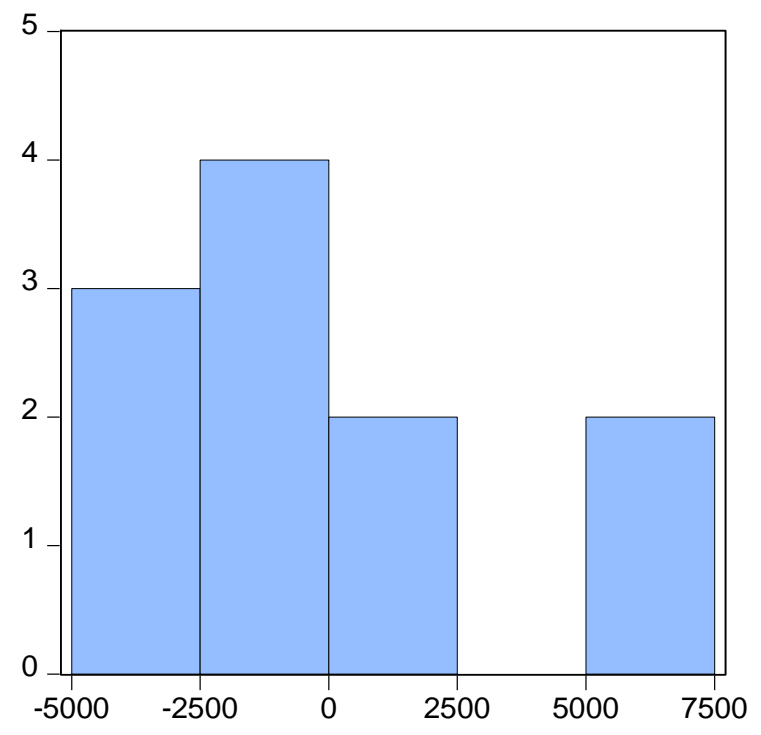

\begin{tabular}{|lc}
\hline \multicolumn{2}{|l}{ Series: Residuals } \\
Sample 2006 2016 \\
Observations & 11 \\
& \\
Mean & $1.24 \mathrm{e}-12$ \\
Median & -603.0705 \\
Maximum & 5731.120 \\
Minimum & -3907.118 \\
Std. Dev. & 3219.672 \\
Skewness & 0.674377 \\
Kurtosis & 2.343209 \\
& \\
Jarque-Bera & 1.031483 \\
Probability & 0.597058 \\
\hline
\end{tabular}

* EViews 10 program

Figure 2 
Null hypothesis H0: The existence of normal distribution Prob> 0.05

Alternative hypothesis H1: There is no normal distribution Prob> 0.05

We note from Figure 2 that the probability value is equal to (0.597058) which is greater than the level of significance $(0.05)$. Therefore, we accept the null hypothesis, which is the presence of a normal distribution of the remainder, and we notice that from the graphical representation.

Table 15. Heteroskedasticity Test: ARCH

\begin{tabular}{|c|c|c|c|c|}
\hline F-statistic & 0.276346 & \multicolumn{2}{|c|}{ Prob. F $(1,8)$} & 0.6134 \\
\hline Obs*R-squared & 0.333898 & \multicolumn{2}{|c|}{ Prob. Chi-Square (1) } & 0.5634 \\
\hline \multicolumn{5}{|c|}{ Test Equation: } \\
\hline \multicolumn{5}{|c|}{ Dependent Variable: RESID ${ }^{\wedge}$} \\
\hline \multicolumn{5}{|c|}{ Method: Least Squares } \\
\hline \multicolumn{5}{|c|}{ Date: $12 / 09 / 19 \quad$ Time: $21: 12$} \\
\hline \multicolumn{5}{|c|}{ Sample (adjusted): 20072016} \\
\hline \multicolumn{5}{|c|}{ Included observations: 10 after adjustments } \\
\hline Variable & Coefficient & Std. Error & t-Statistic & Prob. \\
\hline $\mathrm{C}$ & 8260124. & 5280871. & 1.564160 & 0.1564 \\
\hline$\underline{\operatorname{RESID}} 2(-1)$ & 0.183588 & 0.349236 & 0.525686 & 0.6134 \\
\hline R-squared & 0.033390 & \multicolumn{2}{|c|}{ Mean dependent var } & 10133697 \\
\hline Adjusted R-squared & -0.087436 & \multicolumn{2}{|c|}{ S.D. dependent var } & 11816996 \\
\hline S.E. of regression & 12322789 & \multicolumn{2}{|c|}{ Akaike info criterion } & 35.66866 \\
\hline Sum squared resid & $1.21 \mathrm{E}+15$ & \multicolumn{2}{|c|}{ Schwarz criterion } & 35.72917 \\
\hline Log likelihood & -176.3433 & \multicolumn{2}{|c|}{ Hannan-Quinn criter. } & 35.60227 \\
\hline F-statistic & 0.276346 & \multicolumn{2}{|c|}{ Durbin-Watson stat } & 1.757890 \\
\hline $\operatorname{Prob}(F-$-statistic) & 0.613362 & & & \\
\hline
\end{tabular}

* EViews 10 program

We can note from the test and from Table 15 that:

Null hypothesis H0: There is a homogeneity in the error variance Prob> 0.05

Alternative hypothesis H1: There is no homogeneity in the error variance Prob> 0.05

We accept the null hypothesis because of the existence of a homogeneity in the error F-statistic prob $(0.6134)>(0.05)$

We accept the null hypothesis because of the existence of a homogeneity in the error Obs*R-squared rob $(0.5634)>(0.05)$

\section{Error Correction Form}

We add the error correction factor as an independent variable to the model to find the estimated regression equation in the short term

Table 16. Estimated short-run regression equation

\begin{tabular}{|c|c|c|c|c|}
\hline \multicolumn{5}{|c|}{ Dependent Variable: DPCO } \\
\hline \multicolumn{5}{|c|}{ Method: Least Squares } \\
\hline \multicolumn{5}{|c|}{ Date: $12 / 09 / 19$ Time: $21: 15$} \\
\hline \multicolumn{5}{|c|}{ Sample (adjusted): 20072016} \\
\hline \multicolumn{5}{|c|}{ Included observations: 10 after adjustments } \\
\hline Variable & Coefficient & Std. Error & t-Statistic & Prob. \\
\hline DNE & 0.029772 & 0.017434 & 1.707646 & 0.0261 \\
\hline $\mathrm{E} 2(-1)$ & -0.337997 & 0.269141 & -1.255838 & 0.0446 \\
\hline R-squared & -1.084195 & \multicolumn{2}{|c|}{ Mean dependent var } & 2167.575 \\
\hline Adjusted R-squared & -1.344719 & \multicolumn{2}{|c|}{ S.D. dependent var } & 1635.668 \\
\hline S.E. of regression & 2504.612 & \multicolumn{2}{|c|}{ Akaike info criterion } & 18.66651 \\
\hline Sum squared resid & 50184661 & \multicolumn{2}{|c|}{ Schwarz criterion } & 18.72703 \\
\hline Log likelihood & -91.33256 & \multicolumn{2}{|c|}{ Hannan-Quinn criter. } & 18.60012 \\
\hline $\begin{array}{l}\text { Durbin-Watson stat } \\
* \text { EViews } 10 \text { program }\end{array}$ & 1.201879 & & & \\
\hline
\end{tabular}


Table 18. Least Squares

\begin{tabular}{lllll}
\hline $\begin{array}{l}\text { Dependent Variable: PCO } \\
\text { Method: Least Squares }\end{array}$ & & & \\
Date: $12 / 09 / 19 \quad$ Time: $21: 18$ & & & \\
Sample: 2006 2016 & & & & \\
Included observations: 11 & & & & \\
\hline Variable & Coefficient & Std. Error & t-Statistic & Prob. \\
\hline C & 26142.11 & 3171.147 & 8.243739 & 0.0000 \\
IN & -680.6749 & 587.1614 & -1.159264 & 0.2762 \\
\hline R-squared & 0.129921 & Mean dependent var & 23638.46 \\
Adjusted R-squared & 0.033246 & S.D. dependent var & 7832.679 \\
S.E. of regression & 7701.376 & Akaike info criterion & 20.89915 \\
Sum squared resid & $5.34 \mathrm{E}+08$ & Schwarz criterion & 20.97150 \\
Log likelihood & -112.9453 & Hannan-Quinn criter. & 20.85355 \\
F-statistic & 1.343893 & Durbin-Watson stat & 0.578002 \\
Prob(F-statistic) & 0.276180 & & \\
\hline
\end{tabular}

* EViews 10 program

$$
\text { PCO }=26142.1064059-680.674948964 * I N
$$

Notes on the previous Table 18

Null hypothesis H0: The variable has significant significance if Prob> 0.05

Alternative hypothesis H1: the variable has no significant significance if Prob>0.05

Prob (F-statistic) (0.276180) is higher than the significance level (0.05), that is, there is no significant significance for F-statistic and we take the alternative theory

The prob for the independent variable $(0.27620)$ (IN) is higher than the significance level $(0.05)$, meaning that there is no significant significance for (IN) and take the alternative theory.

Thus, this model is inappropriate and it is not possible to find a discretionary relationship in the short or long term

\section{Discussion of the Results}

\section{The first hypothesis:}

We accept the null hypothesis (H0) that there is a positive positive relationship between the gross domestic product and private consumption at the level of significance (0.05) and that about $97.5 \%$ of the change in private consumption is caused by a change in the gross domestic product.

\section{The second hypothesis:}

We accept the null hypothesis that there is a positive direct relationship between the number of workers and private consumption at the significance level (0.05) and that about $83.1 \%$ of the change in private consumption is caused by a change in the number of workers.

\section{The third hypothesis:}

We accept the alternative hypothesis H1. There is no negative inverse relationship between the rate of inflation and private consumption at the significance level (0.05). The reasons for this could be the state of the economic recession, the stability or decline in prices, and the state of volatility in this period, as its impact was not evident on private consumption. And the inflation rate factor was not a causal relationship in the study period, as a study by (Luis J. Álvarez2011) indicated that the change in consumer prices was limited by the presence of inflation in oil prices in the euro area.

\subsection{Recommendations}

1. Seek to increase the number of workers and reduce unemployment, especially among females.

2. Replace local labor with foreign workers within the legislative frameworks.

3. Promote ways to increase gross domestic product, especially foreign direct investment.

4. The state enters into adjusting prices to achieve benefit for the product and the consumer. 
5. Increase the minimum wage in the private sector.

6. Adopting an expansionary fiscal policy to increase government spending.

\section{References}

Al qadi, D., Abdullah, S., \& Al-Bayati, M. (2005). Statistics for Administrators and Economists. Dar Al-Hamed, Amman: Jordan.

Al-Amr Hassan Abdel-Rahman et al.. (2018). Determinants of family saving in Jordan. The Jordanian Journal of Economic Sciences, 5(1).

Anghelache, C. (2011). Analysis of the Correlation between GDP and the Final Consumption. Theoretical and Applied Economics, 9(562), 129-138.

Awad, T. (2015). Introduction to Macroeconomics. Dar Wael, Amman: Jordan.

Bani Hani, A. (2013). Principles of Microeconomics. Dar Al-Mustakbal for Publishing and Distribution, Amman: Jordan.

Dawood, H. (2010). Principles of Macroeconomics. Dar Al-Maysarah, Amman: Jordan.

Hammoud, K., \& Al-Kharsha, Y. (2007). Human Resources Department. Dar Al-Maysarah, Amman: Jordan.

Hardan, T. (1997). Principles of Economics. Dar Al-Manhaj, Amman: Jordan.

Ibrahim, K. (2015). The effect of excessive consumption on the environment and the stability of price levels in the Iraqi economy during the years (2005-2013). Iraqi Journal of Market Research and Consumer Protection, 7(1).

Jordan Central Bank. Retrieved from www.cbj.gov.jo

Jordanian Department of Statistics. Retrieved from www.dos.gov.jo

Jordanian Ministry of Labor. Retrieved from www.mol.gov.jo

Klinger \& Weber. (2020). GDP-employment decoupling in Germany. Structural Change and Economic Dynamics, $52,82-98$.

Luca, C., Lars, F., Sharolyn, A., James, W., \& Paul, C. S. (2020). Going beyond Gross Domestic Product as an indicator to bring coherence to the Sustainable Development Goals. Journal of Cleaner. Production, 2481, Article 119232, March 2020.

Luis, J. Á., Hurtado, S., Sánchez, I., \& Thomas, C. (2011, January-March). The impact of oil price changes on Spanish and euro area consumer price inflation. Economic Modeling, 28(1-2), 422-431.

Maciej, W., Joanna, D., Aleksandra, G., \& Tomasz, B. (2019). Relations of GDP growth and development of SMEs in Poland. Procedia Computer Science, 159, 2470-2480.

Saleh, B. M. A-M. (2018). Estimation of the Total Consumption Function in the Palestinian Economy (1994-2016). Master Thesis, Islamic University of Gaza, Palestine.

Svenfelt, A., Alfredsson, E. C., Bradley, K., Fauré, E., Finnveden, G., Fuehrer, P., ... Gunnarsson-Östling, U. (2019). Scenarios for Sustainable Futures beyond GDP Growth 2050. Futures, 111, 1-14.

\section{Copyrights}

Copyright for this article is retained by the author(s), with first publication rights granted to the journal.

This is an open-access article distributed under the terms and conditions of the Creative Commons Attribution license (http://creativecommons.org/licenses/by/4.0/). 